\title{
Studies on the Pyrogenesis of Tobacco Smoke Constituents (A Review)*
}

\author{
by O. T. Chortyk and W. S. Schlotzhauer \\ Richard B. Russell Agricultural Research Center, Athens, Georgia, USA
}

An attempt has been made here to review briefly the latest literature concerning experiments on the thermal decompositions of tobacco constituents. The last survey of such work was included as a section in a general review on the demical composition of tobacco and tobacco smoke, published in 1968 (1). This review will deal with pyrolytic experiments on tobacco compounds conducted since then. Experiments in related fields will be mentioned only where similarities of mechanisms or results are apparent. This summary is a result of our efforts to gain a perspective of this field of research for the purpose of evaluating future studies and thus also may be of benefit to others.

Pyrolytic experiments generally are conducted for the purpose of correlating selected cigarette smoke components with their leaf precursors or to determine which components previously reported in tobacco smoke or potentially present therein can arise from the thermal degradation of a specific leaf constituent. Consequently, the pyrolytic experiments reviewed here have been summarized in terms of leaf constituents under the following general headings:

I. Tobacco and tobacco extracts,

II. Hydrocarbons and terpenoids,

III. Acids and derivatives,

IV. Amino acids and proteins,

V. Nitrogenous bases,

VI. Carbohydrates,

VII. High molecular weight compounds,

VIII. Additives and agricultural hemicals.

\section{TOBACCO AND TOBACCO EXTRACTS}

Sohlotzhauer and Schmeltz (2) studied the pyrolytic production of aromatic hydrocarbons from the hexane extract of tobacco leaf. They found that although the extract constitutes but $6 \%$ of the dry leaf weight, it contributes more than $20 \%$ of the neutrals of the total tobacco pyrolysate. The results for benzo(a)pyrene (BaP) were even more disproportionate. Yields of $\mathrm{BaP}$ for the fraction were $60 \%$ of the total, while the hexaneextracted leaf residue yielded $40 \%$ of the total BaP. Further studies on specific constituents of the hexane

- Receired for publication: 29th January, 1973. extract (3) involved the pyrolyses of dotriacontane, stearic acid, linoleic acid, phytol, methyl linoleate, squalene, and $\beta$-sitosterol. Straight chain aliphatic compounds, such as hexane, stearic acid, and dotriacontane, yielded significant quantities of aromatic products with alkyl side chains, but less than unsaturated compounds such as linoleic acid, squalene, and phytol. Apparently, existing double bonds facilitate aromatization. Of the various compounds tested, phytol and $\beta$-sitosterol produced the greatest yields of BaP; $\beta$-sitosterol, in addition, yielded the largest amounts of phenanthrene, presumably due to the internal phenanthrene "skeleton" common to plant steroids.

One of our previous papers summarized the pyrolyses of tobacco extracts (4) and discussed the methodology, temperatures, and apparatus of such experiments. The leaf origins of two types of smoke constituents, the polynuclear aromatic hydrocarbons (PAH) and the phenols, were of special interest. In one experiment. flue-cured tobacco was extracted sequentially with a series of solvents, ranging in polarity from hexane to water, to yield a series of fractions and a tobacco residue (5). Pyrolyses of these fractions (at $800^{\circ} \mathrm{C}$ ) was undertaken to determine the possible contribution of groups of compounds of comparable polarity to the formation of neutrals, phenols, and nicotinonitrile in the pyrolysate of the whole tobacco.

It was shown that the source of about $70 \%$ of the aromatic hydrocarbons, ranging from benzene to $\mathrm{BaP}$, in the pyrolysates, were due to leaf components extractable with hexane and acetone; these extracts amounted to less than $25 \%$ of dry leaf weight. The hexane extractables (7.2\% of leaf weight) accounted for $33 \%$ of the neutral products. The hexane-soluble material of cured tobacco leaf is known to include aliphatic and cyclic paraffins, fatty acids, phytosterols, steryl esters, and terpenes, all preferred precursors of aromatic hydrocarbons. The acetone extract $(17.5 \%$ of leaf weight) contributed an additional $35 \%$ of aromatic hydrocarbons to the pyrolysate, indicating a further extraction of similar PAH precursors. Together, these two extracts contributed $86 \%$ of the $\mathrm{BaP}$ content of a tobacco pyrolysate. The disproportionate contribution of these fractions to BaP formation becomes apparent from the following data: the hexane and acetone fractions, containing hydrocarbons and lipids, yielded about 
$700 \mathrm{mg}$ BaP per gram of material pyrolyzed, while the residual tobacco, consisting mostly of cellulosic material, yielded less than $34 \mathrm{mg}$ of BaP per gram pyrolyzed.

The major volatile phenols, phenol and cresols, obtained in this study were produced by the alcohol extractables and the final tobacco residue, accounting for $38 \%$ and $44 \%$, respectively. The alcohol extractables included the polyphenolic brown leaf pigments and, most probably, lower molecular weight sugars, whereas, the final residue consisted essentially of cellulosic and high molecular weight carbohydrates. Both pigment and carbohydrates have been shown to yield phenols pyrolytically (6) Nicotinonitrile served as a characteristic pyrolytic product of the nicotine alkaloids. It was formed mainly by the ethanol extract, indicating that nicotine compounds and the polymeric brown pigments, containing nicotine, were likely precursors of the nitrile.

A chemical evaluation of tobacco quality (7) of fluecured tobacco was based partially on the gas-dhromatographic identification of pyrolytic products of leaves of different origins. Similar efforts at tobacco-quality evaluation through pyrolysis have involved the correlation of "D values" of various flue-cured tobaccos with their organoleptic properties (8). D values were defined as "the ratio of pyrolytic degradation products of resinuous substances to those obtained from sugars". Such quality correlations then were extended to selected gas-chromatographic peaks of smoke from flue-cured tobaccos (9). Recently, pyrolysates of fermented and nonfermented cigar filler tobacco have been compared (10). The study was undertaken to determine any differences in volatile smoke compounds that might reflect changes in flavor and aroma, whidh accompany the fermentation process. While the neutral fractions showed few differences, the phenols of the fermented tobacco pyrolysate were about $40 \%$ reduced, as compared to the unfermented tobacco pyrolysate. It was concluded that this reduction was consistent with the decrease of leaf carbohydrates and polyphenols during fermentation. Similarly, lower levels of volatile pyridine bases were measured in the pyrolysates of fermented tobacco, consistent with the reduction of nicotine, a major precursor of pyridines, during fermentation.

Pisklov and Modhnachev (Ix) have attempted to correlate the levels of gaseous-phase components in tobacco smoke by pyrolyses of various leaf extracts and selected leaf constituents. The pyrolysate gases produced from paraffin were shown to consist of $40 \%$ alkanes, $20 \%$ each $\mathrm{CO}_{2}$ und $\mathrm{CO}$, and approximately $10 \%$ alkenes. Pyrolysis of pigment produced $60 \% \mathrm{CO}_{2}, 20 \% \mathrm{CO}$, $10 \%$ alkenes, and less than $5 \%$ alkanes. Similarly, cellulose produced $45 \% \mathrm{CO}, 35 \%, \mathrm{CO}_{2}, 10 \%$ alkenes, and $5 \%$ alkanes. By analyses of gases obtained through pyrolysis of various leaf extracts, these workers concluded that the neutral and acid fractions of the petroleum-ether extract and the acid fraction of the diethyl-ether extracts of tobacco leaf are major precursors of alkenes in smoke. The neutral fractions of the petroleum ether, diethyl ether, and aqueous extracts are sources of the alkanes, whereas the waterextractable acids yielded highest levels of $\mathrm{CO}_{2}$.

Thermal decomposition of tobacco has been studied by the technique "of thermogravimetric analysis. Studies are conducted in static or dynamic air, nitrogen, or helium. One analysis (12), conducted in static air, followed the weight losses with heating of several tobacco types and blends and divided the resulting derivativethermogravimetric curves into five distinct zones, for the temperature range $25-800^{\circ} \mathrm{C}$. In Zone I, $25-150^{\circ} \mathrm{C}$, weight loss was due to adsorbed water. All tobaccos exhibited considerable weight loss in Zone III (210 to $350^{\circ} \mathrm{C}$ ), due to volatilization and pyrolysis. Equally drastic weight loss occurred in Zone IV, 350-550 $\mathrm{C}$, attributed to oxidative processes, since weight loss was more pronounced in air than in helium. Weight loss in Zone V (550-800 $\mathrm{C}$ ) usually accounted for only about $2 \rightarrow 5 \%$ of the total weight loss.

Subsequently, the same workers applied thermogravimetric analysis to study the effects of numerous chemical additives (generally at the 10\% level) on tobacco (13). Compounds such as sodium vanadate, ammonium vanadate, sodium borate, boric acid, and sodium tetraborate lowered weight loss in the 150 to $350^{\circ} \mathrm{C}$ range, but then increased weight loss in the $350-500^{\circ} \mathrm{C}$ range as compared to untreated tobacco. Others reversed the weight losses, while additives such as sodium chloride, sodium bromate, potassium dhloride, and sodium dichromate had no effects. In a following study (14), the authors compared their thermogravimetric data with specific smoke constituents and coal temperatures of treated cigarettes. Vanadate and borate salts generally promoted high-temperature oxidations in the $350-500^{\circ} \mathrm{C}$ zone. The smoke of such treated tobacco showed greater content of phenol, $\mathrm{BaP}$, and TPM; also, the coal temperatures were higher. Additives such as sodium nitrate, potassium chlorate, and potassium carbonate increased weight losses in the lower temperature zones and the smoke from treated cigarettes contained less BaP, phenol, and TPM.

As noted above, borate-treated cigarettes showed increases in the smoke levels for phenol, cresols, and BaP. A mixture of sodium tetraborate-boric acid in a $7: 3$ ratio was used in studying the effects of additive upon the temperatures and modes of formation of nicotine, phenol, cresols, and BaP (15). The temperatures of maximum recovery of nicotine were $250^{\circ} \mathrm{C}$ and $450^{\circ} \mathrm{C}$, with free nicotine distilling at $250^{\circ} \mathrm{C}$ and being liberated from a borate salt or complex at the higher temperature. Below $530^{\circ} \mathrm{C}$ und above $710^{\circ} \mathrm{C}$, boratetreated tobacco produced more $\mathrm{BaP}$ than untreated tobacco and there was an indication of borate-complex formation with a BaP precursor. No apparent changes in the mode of formation of the cresols was brought about by the borate additive. The formation of phenol for untreated tobacco, in both air and nitrogen, shows two maxima $\left(400^{\circ} \mathrm{C}, 800^{\circ} \mathrm{C}\right)$. Borate treatment inhibited phenol formation at $400^{\circ} \mathrm{C}$ and enhanced it at $800^{\circ} \mathrm{C}$.

A more recent study (16) concentrated upon the effects 
of an additive on the pyrosynthesis of specific smoke constituents. Hoffmann and Wynder (17) have noted a decrease for smoke phenols, nicotine, $\mathrm{BaP}$, and smoke TPM for cigarettes containing sodium nitrate. They have postulated that the nitrate produced nitrogen oxides which acted as scavengers for radicals, from which the higher aromatic hydrocarbons are synthesized on smoking. In the later experiment (16), Rathkamp and Hoffmann studied the effects of various levels of potassium nitrate $(2.5$ to $8.0 \%)$ on eleven smoke constituents, including indoles, aromatic hydrocarbons, and nitroalkanes, which would be affected in different manners by the nitrogen oxides formed from the additive. As expected, the yields of nitromethane, nitroethane, and nitrobenzene in smoke increased with added amounts of nitrate, while phenanthrene, benz(a)anthracene, and $\mathrm{BaP}$ decreased, due to the free radical scavenging. The nitrate additive had little effect upon the formation of indoles, which supposedly originate from tryptophan. In studies with cigarettes containing $8.3 \%$ sodium nitrate, Terrell and Schmeltz (18) have shown that this additive leads to significantly greater quantities of undesirable vapor-phase constituents such as nitrogen oxides, acetaldehyde, acrolein, and acetonitrile.

\section{HYDROCARBONS AND TERPENOIDS}

Of the tobacco hydrocarbons, dotriacontane has been most extensively pyrolysed, mainly for the purpose of determining the extent of contribution to the formation of aromatic hydrocarbons. Schlotzhauer et al. (19) pyrolysed dotriacontane and identified alkylbenzenes, alkylnaphthalenes, anthracene, phenanthrene, alkylanthracenes, alkylphenanthrenes, fluoranthene, pyrene, and BaP from pyrolysis at $860^{\circ} \mathrm{C}$. Pyrolysis at $650^{\circ} \mathrm{C}$ yielded some alkylbenzenes and, as major products, a homologous series of $C_{7}$ to $C_{17}$-alk-1-enes. They concluded that leaf paraffins contribute to at least three classes of cigarette-smoke constituents as a function of temperature: aromatic hydrocarbons formed by pyrosynthesis at the temperature of the burning cone, monoalkenes and some simple aromatic hydrocarbons produced at the lower temperatures behind the burning cone, and paraffins released into the smoke by distillation at low temperatures (Fig. I).

Figure 1. Thermal effects on a representative tobaccoleaf paraffin (19).

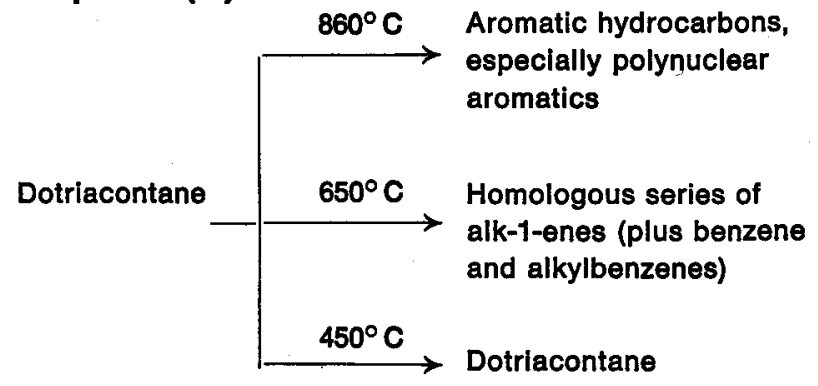

Conclusions of this study have been supported by pyrolytic experiments with n-octacosane $\left(\mathrm{C}_{88} \mathrm{H}_{58}\right)$, at $375^{\circ} \mathrm{C}$, and for varying time periods (20). The experiments indicated that alkanes degrade thermally to a complete homologous series of alkenes and alkanes. Brown (21) has also studied the pyrolytic formation at $500^{\circ} \mathrm{C}$ of monoalkenes from $\mathrm{C}_{5}-\mathrm{C}_{16}$ normal paraffins, as found in petroleum products. Again it was concluded that $n$-alkanes crack to give 1 -olefins, but not branched olefins.

Jenkins and associates (22) studied the thermal decomposition products of radioactively labeled dotriacontane added to cigarettes. The main-stream smoke contributions by ${ }^{14} \mathrm{C}$-dotriacontane were as follows: $0.7 \%$ of the activity was found in $\mathrm{CO}$ and $\mathrm{CO}_{2}, 4.2 \%$ in $\mathrm{C}_{1}-\mathrm{C}_{10}$ compounds, indicative of pyrolysis, and $95 \%$ in the $\mathrm{C}_{31}-\mathrm{C}_{33}$ compounds, indicating that distillation of the hydrocarbon is the major method of transfer to smoke.

Hoffmann and Rathkamp have developed a method for the analysis of fluorenes in smoke (23), and in conjunction with this effort they studied the pyrosynthesis of fluorenes. Pyrolyses at $880^{\circ} \mathrm{C}$, or below, of indene with isoprene or with 1,3-pentadiene produced fluorene and methyl-fluorenes. The authors hypothesized that fluorenes in smoke result from Diels-Alder reactions between indenes and dienes. Similar Diels-Alder condensations have been claimed to occur between isoprenes, formed during $600^{\circ} \mathrm{C}$ flash pyrolyses of polyisoprenes, to yield substituted cyclohexenes (24).

Dare and associates (25) have obtained evidence that olefins (phenylpentenes) undergo intramolecular 1,2and 1,5-migration of hydrogen, upon pyrolysis at $300-400^{\circ} \mathrm{C}$, and that such a mechanism may be involved in the formation of polyolefins of smoke, possibly from solanesol. The study was apparently initiated by the isolation of a polyolefin, containing about $44 \%$ squalene, from smoke condensate.

Jones and Schmeltz have studied the thermal decomposition of the aromatic systems containing the relatively stable $\mathrm{PhCH}=\mathrm{CH}$ - structure in such compounds as trans-cinnamic acid, styrene, distyryl, and cis- and trans-stilbene (26). Products from trans-cinnamic acid will be discussed later, but suffice it to say that the major product was styrene. Hence, the fragmentation of styrene also was examined and 1-phenylnaphthalene was found to be the major pyrolysate constituent. This was also the case for distyryl, which also yielded smaller amounts of the 2-phenyl isomer. At $700^{\circ} \mathrm{C}$, it was noted that cis-stilbene isomerized to transstilbene and also gave styrene, phenanthrene, and naphthalene. Trans-stilbene also isomerized partially and gave similar products. In general, it was shown that stilbene could serve as a precursor of phenanthrene. In conjunction with this study, the thermal stability of toluene, at $900^{\circ} \mathrm{C}$, was examined and was shown to be equal to or greater than that of styrene. No common product patterns were observed.

Halaby and Fagerson (27), in the course of studies on food products, pyrolyzed a number of lipids including the terpenoid $\beta$-carotene and the sterol, cholesterol, 
both reportedly present in cured tobacco leaf. These authors also gave data on pyrolyses of several fatty acids and triglycerides which will be considered in the following section of this review. A number of PAH were identified in these pyrolysates. Approximately ten times as much $\mathrm{PAH}$ was produced by pyrolysis of the sterol as from the other compounds studied, and $\beta$-carotene, surprisingly, gave the lowest yields.

\section{ACIDS AND DERIVATIVES}

Pyrolytic studies on tobacco leaf acids have ranged from the more common aliphatic acids such as acetic, malic, and lactic to the more complex aromatic acids such as cinnamic and caffeic. Schmeltz and Schlotzhauer (28) reported that the pyrolysis of acetic acid (Fig. 2), as the sodium salt, yielded such complex products as mesityl oxide I, mesitylene II, isophorone III, 3,5-dimethyl phenol IV, alkyl benzenes, and higher aromatics. At $500^{\circ} \mathrm{C}$, the first four products predominate, while at $800^{\circ} \mathrm{C}$ the pyrolysates become more complex and more aromatic. Formation of compounds I to IV was explained on the basis of acetone as a pyrolytic intermediate (Fig. 2), and indeed the pyrolytic production of acetone was verified by passing the gaseous pyrolysis products through a solution of 2,4-dinitrophenylhydrazine and isolating the hydrazone of acetone. A similar mechanism has also been proposed by $R_{u}$ denko and Konsinska (29), who pyrolyzed propionic acid at $500-800^{\circ} \mathrm{C}$ and obtained diethyl ketone and a number of alkyl benzenes (Fig. 3).

Geisinger and coworkers (30) have examined the acidic and neutral pyrolytic products of malic acid and the sodium salt of lactic acid. At $620^{\circ} \mathrm{C}$, sodium lactate

Figure 2. Postulated pathway for sodlum-acetate pyroIysle products (28).

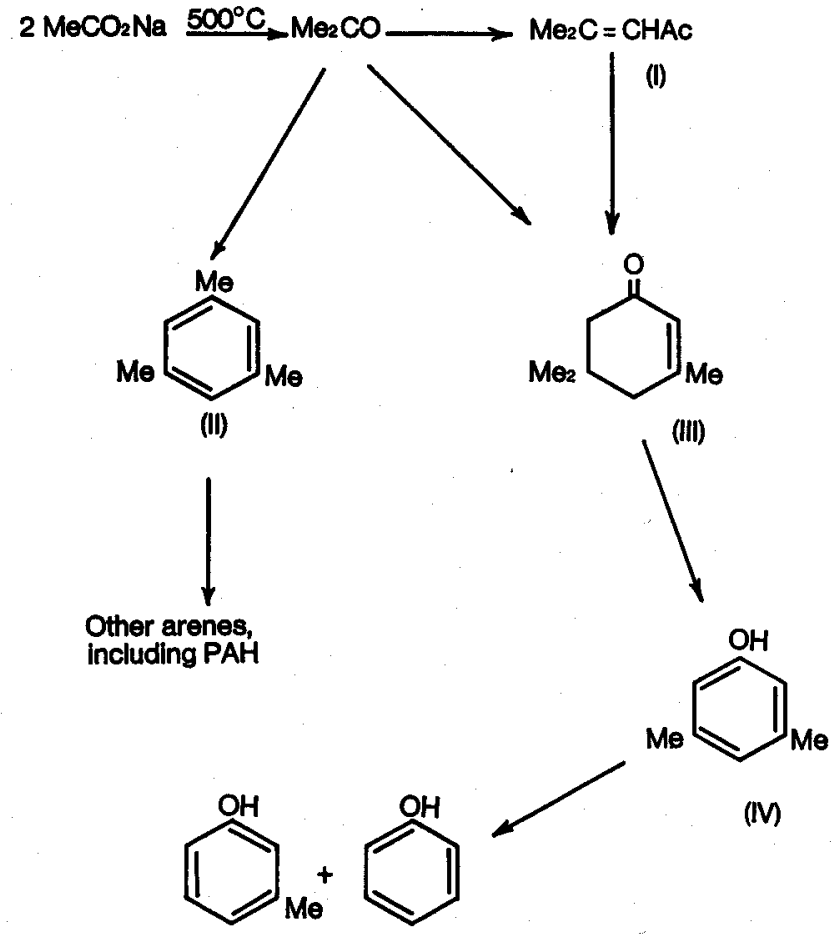

Figure 3. Postulated pathway for proplonic-acid pyroIysis products (29).

Propionic acid $500-800^{\circ} \mathrm{C}$ Diethyl-ketone cyclization

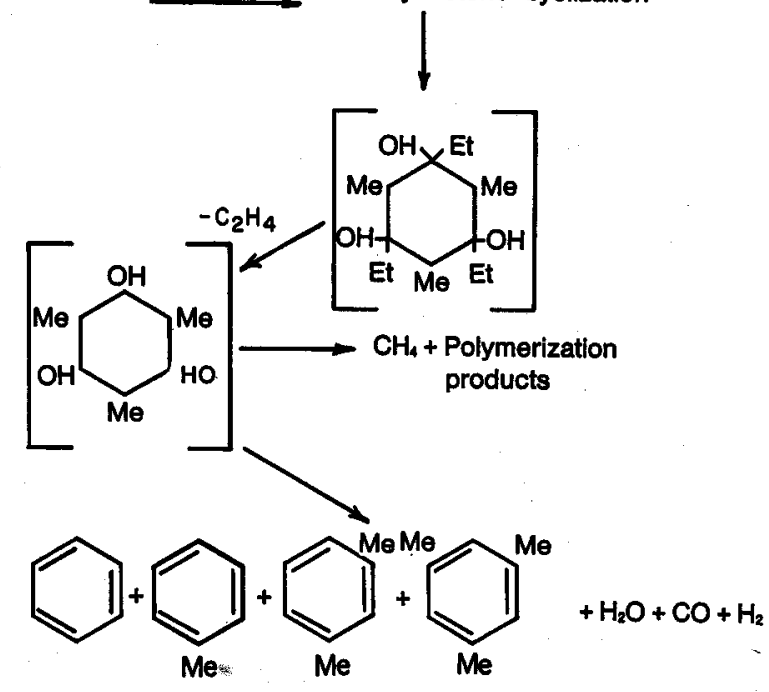

generated formic, lactic, malonic, caprylic, succinic, fumaric, and crotonic acids. The phenolic fraction contained phenol, cresols, and xylenols, with a preponderance of o-cresol and 2,4-xylenol, while the neutral fraction yielded the usual distribution of aromatic hydrocarbons, ranging from benzene to pyrene, interestingly enough, produced in about equal amounts. In the range $500-900^{\circ} \mathrm{C}$, malic acid produced similar aromatic hydrocarbons, with the major products being toluene at $500-600^{\circ} \mathrm{C}$, benzene at $700^{\circ} \mathrm{C}$, indene, naphthalene, and acenaphthylene at $800^{\circ} \mathrm{C}$, and chrysene, naphthalene, and pyrene at $900^{\circ} \mathrm{C}$. The optimum temperature for production of phenols was $700^{\circ} \mathrm{C}$.

Aromatic acids that have been studied include transcinnamic acid (26) and caffeic acid (31). Trans-cinnamic acid was part of a study on stable aromatic systems containing the $\mathrm{PhCH}=\mathrm{CH}$ - structure, as discussed above. In this study, the major product from cinnamic acid was styrene; trans-stilbene, phenanthrene, phenylnaphthalene, and toluene also were produced in large amounts. The formation of trans-stilbene was rationalized to occur through a diphenylcyclobutane intermediate, from the dimerization of cinnamic acid.

Free caffeic acid exists in both tobacco leaf and cigarette smoke, but is more commonly encountered in leaf as a constituent of the chlorogenic-acid isomers. Chlorogenic acid and the related polyphenols, rutin and quercetin, were pyrolyzed many years ago (32) and the major product was always catechol. Again, for caffeic acid, the major product $(31.6 \%)$ was catechol. The neutral fraction was similar in composition to that obtained from cinnamic acid, although much smaller in yield and containing no styrene or transstilbene. It was concluded that caffeic acid moieties in leaf could be major precursors of the catechol found in smoke.

Recently, Patterson et al. (33) pyrolyzed phthalic acid and the 3- and 4-methyl derivatives. They postulated that benzyne was an important reaction-product inter- 
mediate resulting in benzyne dimerization products. Benzoic acid, phenol, cresols, and phenyl benzoate also were major products. It was proposed that phenol and phenyl benzoate arise through the addition of water and benzoic acid, respectively, to the benzyne intermediate. The addition of water to methyl benzynes yielded cresols.

Pyrolytic studies on esters of fatty acids have included ethyl acetate and isobutyl acetate (34), and tripalmitin and tristearin (35). The principal pyrolysis products $\left(345-700^{\circ} \mathrm{C}\right)$ from ethyl acetate were $\mathrm{CO}, \mathrm{CO}_{2}, \mathrm{CH}_{4}$, acetic acid, and acetone, while the isobutyl acetate also yielded isobutylene in addition to the above compounds. It was claimed that the pyrolysis of the ethyl acetate is an ethylene-elimination reaction. The thermal degradation of the triglycerides (35) was studied at $400^{\circ} \mathrm{C}$. Pyrolysates produced fell into two general categories: hydrocarbons and carboxylic acids. Tripalmitin yielded a homologous series of alkanes and alk-1-enes, extending from $C_{7}$ to $C_{17}$ compounds. The major acidic product for tripalmitin was palmitic acid. A series of saturated and monounsaturated carboxylic acids and dicarboxylic acids also was produced. Tristearin gave almost identical acidic products. Kitamura (36) has reported similar results for the pyrolyses of trilaurin and tripalmitin in nitrogen at 300 to $700^{\circ} \mathrm{C}$. In addition to the fatty acids and olefins, noted above, he also identified acrolein, laurone, and palmitone. The ketones supposedly were formed in secondary reactions from fatty acids, while the acrolein was derived from the glycerol portion of the starting material. A previously cited paper (27) reports the pyrolysis of some fatty acids (oleic, linoleic, and palmitic) and corresponding triglycerides (triolein, trilinolein, and tripalmitin) at $700^{\circ} \mathrm{C}$. PAH, including BaP, were isolated and identified in the pyrolysates of all compounds studied, in concentrations as high as $100 \mathrm{ppm}$. Evidence for formation of PAH at $400^{\circ} \mathrm{C}$ was obtained, although in considerably lower yields with no definite quantitative data provided.

Since acetaldehyde is the only tobacco carbonylcompound that has been pyrolyzed recently, it will be included in this section, for convenience. One study was conducted over the $480-540^{\circ} \mathrm{C}$ temperature range and at pressures from 1 to $560 \mathrm{~mm} \mathrm{Hg}$ (37). The rates of production of the major product, methane, and the minor products, hydrogen, ethane, acetone, and propionaldehyde, were measured. The authors suggest a mechanism involving $\mathrm{CH}_{3}, \mathrm{CHO}, \mathrm{H}$, and $\mathrm{CO}$ radicals, which interact among themselves and with acetaldehyde to form the observed products. A similar process of radical formation was involved in another study, which also showed the presence of propene and carbon di. oxide (38).

\section{AMINO ACIDS AND PROTEINS}

Numerous studies have appeared on the pyrolyses of selected amino acids. One study (39) was concerned only with hydrocarbon products analyzed by gas chromatography. Thus, glycine produced methane and propane, alanine produced ethylene and propane, while valine, leucine, and isoleucine yielded methane, ethylene, acetylene, propane, propene, I-butene, 2-butene, butadiene, and 2-methyl-1-butene. Patterson and associates (40) have completed several studies on individual and mixtures of amino acids to examine the role of amino acids as possible precursors of smoke carcinogens. Initially, they pyrolyzed lysine monohydrochloride, leucine, and tryptophan, at $850^{\circ} \mathrm{C}$ in a nitrogen atmosphere. Pyrolysate products contained aromatic hydrocarbons, aromatic nitriles, aromatic bases, and polynuclear aromatic hydrocarbons. Methane, ethylene, acetylene, carbon monoxide, carbon dioxide, and hydrogen cyanide were identified in the gaseous products. The authors concluded that amino acids may be a significant source of the ciliostatic agent, hydrogen cyanide. In a subsequent study (4x), Patterson et al. pyrolyzed phenylalanine over the temperature range $450-950^{\circ} \mathrm{C}$ to determine the optimum temperature for PAH formation, which for isoprene had been found to be $800^{\circ} \mathrm{C}(42)$. For phenylalanine this was determined to be $850^{\circ} \mathrm{C}$.

Pyrolyses of the mixtures phenylalanine-pyrrole or phenylalanine-tryptophan resulted in decreases in yields of isoquinoline, bibenzyl, and phenanthrene as compared to pyrolyses of the individual amino acids. A synergistic effect was noted on the yields of indole and naphthalene. For the copyrolyses, it was suggested that the decreased yields of PAH were due to the formation of higher molecular weight compounds, not assayed, which may constitute tobacco "tar". At low temperatures, phenylalanine anhydride and phenethylamine are the pyrolysis products of phenylalanine. All three compounds have been subjected to pyrolyses at 650 and $850^{\circ} \mathrm{C}(43)$. At $650^{\circ} \mathrm{C}$, phenylalanine and phenylalanine anhydride produced mainly toluene, while phenethylamine formed styrene. Hydrogen cyanide, carbon monoxide, and carbon dioxide again were identified in all pyrolyses. At $850^{\circ} \mathrm{C}$, PAH formation increased and the authors concluded that at high pyrolysis temperatures simultaneous multiplebond cleavages predominate.

It is interesting to contrast the differences in pyrolytic products for amino acids at high and low temperatures. Kato and co-workers (44) examined the low-temperature decomposition of amino acids and their role in the formation of cooked-food aroma. Thus, heating of $\beta$-hydroxy acids, such as serine and threonine, at $280^{\circ} \mathrm{C}$ and $360^{\circ} \mathrm{C}$, respectively, produced nine alkyl pyrazines, as well as diketopiperazines, amines, and carbonyl compounds. Alanine produced no pyrazines. A previous study (45) on the sulfur-containing amino acids, cysteine, cystine, and methionine, pyrolyzed at $270-300^{\circ} \mathrm{C}$, identified a series of aliphatic amines and aldehydes. It was noted that cystine and cysteine produced a popcorn-like aroma while methionine gave off a pickled radish-like odor. Also of interest was the observation that alanine, cystine, and isoleucine and that alanine, isoleucine and methonine were found 
in the pyrolysates of cysteine and cystine, respectively, whereas, methionine produced no amino acids. Subsequently, Smith and associates (46) presented more complete data on the pyrolysis of the sulfur aminoacids, cysteine, cystine, homocystine, methionine, and methionine sulfone at $850^{\circ} \mathrm{C}$. Gases formed during pyrolyses were identified as acetylene, CO, COS, $\mathrm{CS}_{\text {, }}$, $\mathrm{HCN}, \mathrm{CH}_{4}$, and $\mathrm{C}_{2} \mathrm{H}_{4}$. Basic products included pyridines, picolines, toluidines, and quinolines. Neutral products were acenaphthylene, benzene, benzonitrile, biphenyl, fluorene, indene, indole, I- and 2-methylnaphthalene, 2-naphthonitrile, phenanthrene, styrene, o-tolunitrile, and naphthalene. The principal sulfur-containing products were $\mathrm{CS}_{2}, \mathrm{COS}$, and two solids that contained ammonium thiocarbamate, ammonium dithiocarbamate, ammonium carbamate, ammonium carbonate, and ammonium cyanide.

Higman and associates have conducted high-temperature pyrolyses $\left(840^{\circ} \mathrm{C}\right.$ ) on amino acids (proline and glycine) and the non-tobacco proteins, casein, collagen, and $\beta$-lactoglobulin A (47). Pyrolysates of the proteins contained aromatic hydrocarbons, their nitrogen-containing analogs, such as pyridine bases, indole, and quinoline, as well as nitriles, aniline, and phenols (Table 1). Surprisingly, the biologically active BaP was absent in the pyrolysates of casein and collagen. Tobacco proteins are fairly complex and difficult to isolate $(1,48)$. Thus, in a following study, Schmeltz et al. (49) isolated and pyrolyzed a small amount of proteinaceous material from cured tobacco, but it was judged to be impure and the pyrolytic results were not

Table 1. Pyrolytic products of proteins and amino acids (47).

\begin{tabular}{|c|c|c|c|c|}
\hline & Casein & $\begin{array}{c}\text { Colla- } \\
\text { gen }\end{array}$ & Proline & Glycine \\
\hline Pyridine & $+a$ & $+a$ & $+a$ & + \\
\hline 2-Methylpyridine & + & $+a$ & + & + \\
\hline 3- and/or 4-Methylpyridine & + & $+a$ & + & + \\
\hline 3-Vinylpyridine & + & + & & \\
\hline Aniline & + & + & + & \\
\hline Quinoline & $+a$ & + & + . & \\
\hline Isoquinoline & + & + & $+a$ & \\
\hline Benzene & + & + & + & + \\
\hline Pyrrole (toluene) & $+a$ & $+\mathbf{a}$ & $+a$ & + \\
\hline Styrene (xylenes) & + & + & & \\
\hline Benzonitrile & + & + & + & + \\
\hline Indene & + & + & & + \\
\hline o-Tolunitrile & + & + & + & \\
\hline m-Tolunitrile & + & + & + & \\
\hline Naphthalene & + & + & & \\
\hline Indole & + & + & $+a$ & \\
\hline Fluorene & + & & & \\
\hline Phenol & $+\pi$ & $+a$ & & \\
\hline o-Cresol & + & & & \\
\hline$m$-and/or p-Cresol & $+a$ & + & & \\
\hline Ethylphenol & + & + & & \\
\hline Xylenol & + & + & & \\
\hline
\end{tabular}

(a) Principal products. sufficiently reliable for comparison. Generally, it was concluded that pyrolyses of nitrogenous compounds, at high temperatures, tend to produce similar spectra of nitrogen heterocyclics, analogs of aromatic hydrocarbons.

\section{NITROGENOUS BASES}

The copyrolysis of pyrrole with an amino acid has already been mentioned above. There has also been a report of the individual pyrolysis of pyrrole, performed at $850^{\circ} \mathrm{C}(50)$. In addition to $\mathrm{PAH}$, heterocyclics such as quinoline, indole, 2-picoline, and 2-cyanopyridine were obtained. However, the predominant product was hydrogen cyanide, produced in $49 \%$ yield. The authors believe that their data support the concept of carbon-hetero-atom bond cleavage, resulting in the formation of arenes, as previously postulated for thiophene and pyridine (51). Initially, pyrrole is believed to open up to the diradical $\cdot \mathrm{NH}-\mathrm{CH}=\mathrm{CH}-\mathrm{CH}=\mathrm{CH}$. which can then undergo bond cleavage at any position to give a variety of radicals. Thus, the formation of HCN occurs through the rupture of the tautomeric form of the diradical to yield $\mathrm{HN}=\mathrm{CH}^{\cdot}$ and the trimethine fragment $(: \mathrm{CH}-\mathrm{CH}=\mathrm{CH} \cdot)$.

Since nicotine is the most abundant and best known tobacco alkaloid, its pyrolysis has been thoroughly studied $(52,53)$. More recent work $(54)$ on the pyrolysis of nicotine and various alkyl-pyridines has resulted in a proposed mechanism for the thermal degradation

Table 2. Products from nicotine pyrolysis $\left(860^{\circ} \mathrm{C}, \mathrm{N}_{2}\right)(49)$.

$\%$ of pyrolysate

Basic fraction:

Pyridine $\quad 5.3$

2-Methylpyridine $\quad 0.51$

3- and/or 4-Methylpyridine $\quad 8.1$

3-Vinylpyridine $\quad 1.0$

3-Cyanopyridine 25.3

2- and/or 4-Cyanopyridine $\quad 6.2$

Quinoline $\quad 7.2$

Isoquinoline $\quad 1.3$

Nicotine : 16.4

Benzacridines

Benzquinolines

Neutral fraction:

Benzene $\quad 0.40$

Pyrrole $\quad: \quad 1.2$

Toluene $\quad 0.3$

Benzonitrile $\quad 0.69$

2- and/or 4-Cyanopyridine $\quad 0.89$

Indole $\quad 1.2$

Skatole $\quad 0.25$

Styrene

Indene

Naphthalene

Acenaphthene

Anthracene/phenanthrene 
of nicotine. The authors believe that the source of pyridines in smoke, especially 2- and 4-substituted pyridines, is the nicotine of the leaf. Schmeltz (49) also studied nicotine and identified a number of previously unreported compounds in the nicotine pyrolysates (Table 2). These included pyrrole, acenaphthene, indole, skatole, and anthracene and/or phenanthrene. However, the presence of dibenzacridines and dibenzcarbazole, previously reported in nicotine and pyridine pyrolysates, could not be confirmed (55).

In a related experiment, Bruzel and Schmeltz (56) pyrolyzed nicotinamide, which occurs in leaf and smoke, and diphenylalanine, carbazole, and acridine, which only occur in smoke. This high temperature study $\left(1050^{\circ} \mathrm{C}\right)$ was undertaken in order to determine whether or not biologically active nitrogen heterocyclics such as benzcarbazoles or benzacridines could result from the above compounds. However, none could be positively identified. The major product from diphenylamine was carbazole, while that from nicotinamide was benzonitrile. Surprisingly enough, carbazole and acridine proved to be very stable at such a high temperature, as evidenced by the recovery of large amounts of starting material and the identification of minor pyrolysate constituents like benzene, pyridine, and methylindoles. Such stability might indicate that carbazole and acridine are end products of free-radical mechanisms occurring during the smoking process.

\section{CARBOHYDRATES}

Discussion in this section will be limited to the simple sugars found in tobacco; work on high molecular weight carbohydrates, such as cellulose, will be described in the following section.

Since sugars are important food constituents, numerous thermal degradation studies on sugars in foods have been conducted and reviewed (57). Generally, pyrolytic studies on sugars have been conducted at low temperatures or by low-temperature distillations, under vacuum. Thus, sucrose was pyrolyzed in a distilling flask by heating with a gas burner (58). The chloroform-soluble pyrolysate products were identified by isothermal gas chromatography and shown to consist of ketones, lactones, furans, and cyclopentanone derivatives. Of the thirty identified products, 5-methylfurfural was the major one, as expected. These products were very similar to those obtained from an aqueous acid stannous-chloride degradation of glucose, which is used to prepare 5-methylfurfural.

The low-temperature $\left(175-275^{\circ} \mathrm{C}\right)$ thermal decomposition of ${ }^{14} \mathrm{C}$-labeled glucose (uniformly or at positions $I$, 2 , or 6) has been studied in vacuo (59). The reaction produced mainly $\mathrm{CO}$, furfural, and an acidic fraction. The distribution of the radioactivity among the products was used to determine the contribution of individual carbon atoms to the products. The results indicated that the main pathway for furfural formation involved expulsion of $\mathrm{C}-6$ of the glucose skeleton, while the acids are formed preferentially with the
Table 3. Percent distribution of products from pyrolysis $\left(840^{\circ} \mathrm{C}, \mathrm{N}_{2}\right)(47)$.

\begin{tabular}{|c|c|c|c|}
\hline & Cellulose & Glucose & Fructose \\
\hline \multicolumn{4}{|l|}{ Neutrals: } \\
\hline Benzene & 25.7 & 17.6 & 27.4 \\
\hline Toluene & 24.9 & 14.6 & 14.2 \\
\hline Furfural & & 7.4 & 12.5 \\
\hline Ethylbenzene & 2.2 & 4.7 & 3.5 \\
\hline Styrene, xylenes & 6.1 & 7.1 & 7.0 \\
\hline 5-Methylfurfural & & 2.3 & 1.0 \\
\hline p-Methylstyrene & 3.7 & 4.6 & 3.7 \\
\hline Indene & 6.0 & 6.3 & 10.6 \\
\hline Naphthalene & 10.3 & 8.0 & 5.7 \\
\hline Alkylnaphthalene & 4.3 & 3.3 & 2.3 \\
\hline Biphenyl & & & 0.4 \\
\hline Acenaphthylene & 1.3 & 1.1 & 0.4 \\
\hline Fluorene & 1.8 & 0.4 & 0.5 \\
\hline Dibenzofuran & & & 0.2 \\
\hline Phenanthrene, anthracene & 0.9 & 0.8 & 0.8 \\
\hline \multicolumn{3}{|c|}{ Alkylphenanthrene, alkylanthracene } & 0.2 \\
\hline \multicolumn{3}{|l|}{ Fluoranthene } & 0.03 \\
\hline Pyrene & 2.1 & & 0.13 \\
\hline \multicolumn{4}{|l|}{ Phenols: } \\
\hline Phenol & 67.5 & 59.6 & 77.9 \\
\hline o-Cresol & 8.4 & 10.6 & 4.8 \\
\hline m-Cresol, p-cresol & 12.4 & 11.7 & 4.3 \\
\hline Xylenol & 4.2 & 3.9 & 2.3 \\
\hline
\end{tabular}

involvement of C-1. By contrast, high-temperature pyrolysis of sugars yield much more complex products. For example, in one high-temperature study (47), involving the pyrolysis of glucose and fructose (at $840^{\circ} \mathrm{C}$ ), the products included condensed ring hydrocarbons, simpler aromatic hydrocarbons, furfurals, and phenols (Table 3).

Since glucose and sucrose are generally added to tobacco to produce improved flavors, their thermal degradation and transfer to smoke have been examined by using radioactively labeled D-glucose- ${ }^{14} \mathrm{C}$ and sucrose- ${ }^{14} \mathrm{C}(60,61)$. Both compounds were added to the Burley tobacco portion of blended cigarettes, which were then smoked. Very small amounts $(0.5 \%)$ of both sugars were transferred into smoke. The largest portion of the radioactivity (about $40 \%$ ) was found in the sidestream gases, in carbon dioxide, while the mainstream gas phase contained about $5 \%$. About $3 \%$ of the total activity was found in the TPM and an equal amount accumulated in butts, which contained 1,6 anhydro- $\beta$-D-glucopyranose and 5-(hydroxymethyl)2-furaldehyde (HMF). Radioactive HMF and 5-methyl2-furaldehyde were identified in the neutral fraction of smoke. The authors identified thirteen constituents (mainly furans and carbonyls) in the gas phase of smoke, which were partially derived from the labeled sugars. Acetone and acetaldehyde were formed in high radiochemical yields $(0.05$ to $0.1 \%$ ). They concluded that the relative contributions to the smoke from the sugars were greatest for the furans, intermediate for acetonitrile, and smallest for the carbonyls. 


\section{HIGH MOLECULAR WEIGHT CONSTITUENTS}

Proteins, polysaccharides, and the polymeric polyphenols are the principal high molecular weight materials of tobacco (48). The polysaccharides include cellulose, starch, and pectins. The polyphenols include lignin and the brown pigments. Together they comprise more than $30 \%$ of tobacco leaf. By reason of their abundance, it is expected that they would be important contributors to most smoke constituents. In pyrolytic studies, however, they have not received their share of attention in proportion to their abundance. One reason may be the lack of isolation methods that yield the pure material, as noted for the proteins above.

Cellulose is the most abundant polysaccharide in tobacco and its pyrolysis was studied in conjunction with simple sugars, as shown in Table 3. As seen from the data, the important pyrolysate constituents were phenol, benzene, toluene, and naphthalene. The pyrolytic formation of phenols from carbohydrates was established previously (6). It is also interesting to compare the levels of $\mathrm{BaP}$ produced by simple sugars as compared to cellulose. Thus, micrograms of $\mathrm{BaP}$ per gram of material pyrolyzed were 48,98 , and 289 for glucose, fructose, and cellulose, respectively.

In another study, Benner et al. (62) studied the effect of a boric acid-sodium tetraborate additive on lignin and cellulose pyrolyses and the effects on phenol formation. Applying the technique of thermogravimetric analysis, it was concluded "that borate salts do affect the recovery of phenol and cresols from leaf constituents such as lignin and cellulose and may be partially responsible for the increased levels of phenol obtained from the isothermal pyrolysis of borate-treated tobacco". They postulated that borate formed a complex, with cellulose, which was stable at low temperatures but decomposed at higher temperatures. This was based on the observation that phenol recovery reached a maximum at $650^{\circ} \mathrm{C}$, while that for untreated cellulose was about $100^{\circ} \mathrm{C}$ lower.

So far, no conclusive studies have appeared on tobacco starch. However, a report has appeared on the pyrolyses of pectin, $\alpha$-D-galacturonic acid and its methyl ester (63). Pyrolysates were examined by gas chromatography (GC) and an effort was made to correlate the degree of methylation and degree of polymerization of the pectin with certain GC peaks. The efforts were not completely successful, but products such as formaldehyde, methyl formate, acrolein, and methanol were identified.

Structurally, the most interesting high molecular weight substances of tobacco are the polymeric brown pigments (1). The polyphenolic pigments also contain bound proteinaceous material and nicotine. Pyrolysis of the pigment yielded a basic fraction, which contained degradation products characteristic of nicotine. It is interesting to compare these results to those obtained from tobacco pyrolysate $\left(850^{\circ} \mathrm{C}\right)$ and constituents of cigarette smoke condensate (49) (Table 4). It has also been established that pyrolysis of pigment material
Table 4. Comparison of bases found in varlous pyrolysates and tobacco smoke condensate (49).

\begin{tabular}{|c|c|c|c|c|}
\hline & \multirow{2}{*}{\multicolumn{3}{|c|}{ Pyrolysates }} & \multirow{3}{*}{$\begin{array}{c}\text { Tobacco } \\
\text { smoke } \\
\text { conden- } \\
\text { sate }\end{array}$} \\
\hline & & & & \\
\hline & $\begin{array}{c}\text { To- } \\
\text { bacco }\end{array}$ & $\begin{array}{c}\text { Pig- } \\
\text { ment }\end{array}$ & $\left|\begin{array}{c}\text { Nico- } \\
\text { tine }\end{array}\right|$ & \\
\hline \multirow{6}{*}{$\begin{array}{l}\text { Pyridine } \\
\text { 2-Methylpyridine } \\
\text { 2,6-Lutidine } \\
\text { 3- and/or 4-Methylpyridine } \\
\text { 2,4- and/or 2,5-Lutidine } \\
\text { 2,3-Lutidine and/or collidine }\end{array}$} & + & + & + & + \\
\hline & + & + & + & + \\
\hline & & & & + \\
\hline & + & + & + & + \\
\hline & & + & & + \\
\hline & & & & + \\
\hline 3-Ethylpyridine & & + & & + \\
\hline 3,5-Lutidine & & + & & + \\
\hline 3,4-Lutidine & & & & + \\
\hline 3-Vinylpyridine & + & + & + & + \\
\hline Pyrrole & & & + & + \\
\hline Pyridine-3-aldehyde & & & + & + \\
\hline Nicotinonitrile & + & + & + & + \\
\hline 2- and/or 4-Cyanopyridine & & & + & \\
\hline Methyl-3-pyridyl ketone & & & & + \\
\hline Nicotine & + & & + & + \\
\hline Nornicotine/myosmine & + & & & + \\
\hline Anabasine & + & & & + \\
\hline Metanicotine & & & & + \\
\hline 2,3-Bipyridyl & & & & + \\
\hline Quinoline & + & + & + & + \\
\hline Isoquinoline & + & + & + & + \\
\hline Aminoquinoline & & & + & \\
\hline 7,8-Benzoquinoline & + & & & \\
\hline Other benzoquinolines & + & & + & \\
\hline Alkylquinolines & + & & & \\
\hline Benzacridines & + & & + & + \\
\hline Benzcarbazoles & & & & + \\
\hline
\end{tabular}

results in formation of phenols and polynuclear aromatic hydrocarbons, including $\mathrm{BaP}(\mathrm{I})$.

Leaf and smoke pigments also have been studied by the techniques of thermogravimetric and differential thermal analyses (64). The thermal decomposition patterns for leaf pigments indicated that three weight-loss maxima existed at about 300,450 , and $600^{\circ} \mathrm{C}$ and that leaf pigment would have to undergo significant alteration during possible conversion into smoke pigment.

\section{ADDITIVES AND AGRICULTURAL CHEMICALS}

Sugars are important constituents of tobacco flavoringagent preparations or additives and the pyrolysates of sugars have been discussed above. Other components of flavoring additives or casing sauces include licorice, cocoa, sorbitol, glycerol, glycols, citric acid, malic acid, fixatives such as gums and balsams, and various aromatics. These preparations are used to moderate or improve smoking quality and aroma and may be added to cigarette tobacco up to $5 \%$ by weight, and much more to pipe tobacco. However, so far, few of the above compounds have been subjected to pyrolytic studies. 
Menthol is the only major cigarette additive that has received some attention and reports have appeared on its thermal degradation and distribution in smoke. Schmeltz and Schlotzhauer (65) studied the pyrolysis of (d,1)-menthol and reported that at $600^{\circ} \mathrm{C}$ much unreacted menthol was recovered from the neutral fraction, in addition to the major products 3 -methylcyclohexanone and a vinyl methylcyclohexanone. The latter product was believed to arise from the loss of methane from the propyl side-chain of menthol. An $860^{\circ} \mathrm{C}$ pyrolysis resulted in a more complex product, with unreacted menthol accounting for only $16 \%$ of the neutral fraction. Products included phenols, benzene, toluene, styrene, naphthalene, and other PAH, probably formed by free radical mechanisms, not occurring at the lower temperature.

More recently, Jenkins et al. (66) studied the distribution of ${ }^{14} \mathrm{C}$-menthol $(\mathrm{U})$ in the total cigarette smoke. The mainstream smoke contained $28.9 \%$ of the total activity, the sidestream smoke contained $44.3 \%$, and the butt contained $26.9 \%$ of the activity. In the mainstream, $98.9 \%$ of the activity was unchanged menthol, and it was concluded that menthol simply distils ahead of the burning zone and does not build up in the butt.

Millions of pounds of pesticides, insecticides, and assorted agricultural demicals are used annually in the cultivation of tobacco crops. It is inevitable that a small percentage of the chemicals find their way into the final tobacco products. Consequently, it is important to determine the fate of these pesticide residues in the smoking process and the identity and toxicity of their pyrolytic products.

Chopra and associates have conducted extensive studies on the degradation of $P, P^{\prime}-D D T(67-69)$. Even though the use of $p, p^{\prime}-D D T$ has been banned in the U.S. and several other countries, it is still used in some parts of the world and is present in stored tobacco, grown before the ban was effected. The initial experiment involved pyrolysis of pure DDT in a quartz tube at $900^{\circ} \mathrm{C}(67)$, which yielded products such as dichloromethane, $\mathrm{CHCl}_{3}, \mathrm{CCl}_{4}, \mathrm{CHCl} \times \mathrm{CCl}_{2}, \mathrm{CCl}_{2}=\mathrm{CCl}_{2}$, dilorobenzene, $\mathrm{CCl}_{8}-\mathrm{CCl}_{3}, \alpha, p$-dichlorotoluene, $\mathrm{p}, \mathrm{p}^{\prime}$-dichlorobiphenyl, cis-p,p'-dichlorostilbene, $p, p^{\prime}-D D M, p, p^{\prime}-D D E$, $\dot{p}, p^{\prime}-T D E$, and others. The same paper also reported the results of copyrolyses of DDT with tobacco. The following compounds were identified in a pentane extract of the smoke condensate: bis-(p-dhlorophenyl)-methane, $p, p^{\prime}$-dichlorobenzophenone, $p, p^{\prime}-D D M$, trans- $p, p^{\prime}$-dichlorostilbene, $\mathrm{p}, \mathrm{p}^{\prime}-\mathrm{DDE}, \mathrm{p}, \mathrm{p}^{\prime}-\mathrm{TDE}^{\prime}$ and $\mathrm{p}, \mathrm{p}^{\prime}-\mathrm{DDT}$. The authors postulated fragmentation mechanisms involving free radicals and carbenes and that dichlorocarbene and trichloromethyl radicals may be some of the primary alkylating agents in tobacco smoke. The companion paper (68) on the $900^{\circ} \mathrm{C}$ pyrolysis of p,p'-DDT reported on the methods of isolation and identification of the 14 degradation products.

In a subsequent study (69), Chopra and Sherman attempted to determine the presence in tobacco smoke of methyl chloride, dichloromethane, and chloroform, which could arise from the trichloromethyl moiety of
p.p'-DDT. No chloroform could be detected in the smoke of pure tobacco samples, while for tobacco samples with p,p'-DDT, about $4.6 \%$ of the trichloromethyl moiety of $p, p^{\prime}$-DDT is converted into chloroform. No dichloromethane could be detected, indicating that dichlorocarbene is not an intermediate or that it reacts rapidly with other constituents of tobacco smoke. The amount of methyl hloride found was about 2000 micrograms per gram of tobacco smoked. It was concluded that the methyl chloride comes from inorganic chlorine in tobacco and "that the contribution of p,p'-DDT to methyl chloride in tobacco smoke is not substantial" .

Maleic hydrazide (MH) is the most commonly used systemic tobacco sucker-control agent. Recently, Patterson and associates (7o) reported results from the $850^{\circ} \mathrm{C}$ pyrolyses of $\mathrm{MH}$ and $\mathrm{N}, \mathrm{N}$-dimethyldodecylamine (DDA), another widely used sucker inhibitor. More than forty compounds were identified in the liquid and gaseous phases of the pyrolysates. Among the substances produced were $\mathrm{CO}, \mathrm{HCN}, \mathrm{NH}_{3}$, phenol, cresols, $\mathrm{BaP}$, and other PAH. The basic fraction from the DDA pyrolysis was found to contain some unreacted starting material. Changes in the pyrolysis atmosphere from nitrogen to air did not result in significant changes in the total yields of the neutral, acid, or base fractions. Currently, the authors are engaged in studies on the copyrolysis of these sudker inhibitors with tobacco (71), and these results should be more meaningful to the smoking and health problem.

\section{DISCUSSION}

This discussion of a number of recent pyrolytic studies is presented in the hope of further elucidating the nature of physical and chemical processes occurring during the smoking process. In attempting to correlate the data obtained from model systems with the actual smoking process, however, one must be fully aware of the complexity of the latter compared to controllable experimental conditions. Tobacco smoke is a complex system with possibly thousands of components contained in a highly concentrated aerosol phase and a gaseous phase. The processes responsible for this complex two-phase system occur within, and immediately behind, the burning zone of a cigarette or cigar, and in an atmosphere rich in carbon monoxide, hydrosen, and methane, indicative of a reducing environment (72): Appropriately; the majority of pyrolytic studies in this review were conducted in non-oxidative media such as nitrogen or helium, although combustion in air frequently was performed for purposes of comparison. Cigarettepaper porosity, for example, may determine in part the quantities of tobacco subjected to oxidative reactions during the smoking process. Temperatures within the burning cone of a cigarette reportedly attain $980-$ $1050^{\circ} \mathrm{C}(73)$, although a temperature of $860^{\circ} \mathrm{C}(74)$ generally is taken as representative. A sharp thermal gradient occurs immediately behind the burning cone with tobacco smoldering by natural convection. Thus, a 
Table 5. Data summary of smoke constituent - leaf precursor relatlonshlps.

\begin{tabular}{l|l}
\hline Smoke constituent(s) & Leaf precursor(s) (Ref.) \\
\hline
\end{tabular}

\section{A. Aclds}

Acetic
Caprylic
Fatty acids (general)
Formic
Malonic
Palmitic
Stearic
Succinic

\section{B. Aldehydes and ketones}

Acetaldehyde
Acetone
Acrolein
Carbonyls (general)
Cyclopentanones
Diethylketone
Formaldehyde
Furfural
5-(hydroxymethyl)-2-
furaldehyde
Isophorone
Laurone
5-methylfurfural
Palmitone
Propionaldehyde

Sugars $(60,61)$

Acetaldehyde (37), esters (34), acetic acid, salt (28)

Pectin (63), triglycerides (36)

Amino acids $(44,45)$, propionic acid (29), sugars $(59,60,61)$

Sucrose (58)

Propionic acid (29)

Pectin (63)

Sugars $(47,59)$

Sugars (58)

Acetic acid, salt (28)

Triglycerides (36)

Sucrose (58)

Triglycerides (36)

Acetaldehyde $(37,38)$

\section{Alkanes}

Alkanes (general)

Ethane

Methane

Propane

\section{Alkenes and alkynes}

Acetylene
Butadiene
1- and 2-butene
Cyclohexenes

Paraffins (11), triglycerides (35), tobacco extracts (11)

Acetaldehyde (37)

Acetaldehyde (37), amino acids $(39,40,46)$, esters (34)

Amino acids (39)

Amino acids $(39,40,46)$

Amino acids (40)

Amino acids (40)

Polyisoprenes (24)

Smoke constituent(s)

Leaf precursor(s) (Ref).

Ethylene

Isobutylene

2-methyl-1-butene

Monoolefins (general)

Polyolefins

Propene

\section{E. Aromatic hydrocarbons}

Monoaromatic hydrocarbons

Polynuclear aromatic hydrocarbons

\section{F. Nitrogenous bases}

Alkyl pyrazines

Amines (general)

Aniline

Aromatic bases

(general)

Aromatic nitrates (general)

Hydrogen cyanide Indole

Isoquinoline

Pyridine bases

Pyrrole

Quinoline

Skatole

Toluidines
Amino acids (39)

Isobutylacetate (34)

Amino acids (40)

Paraffins $(19,20,21)$, triglycerides $(35,36)$, tobacco extracts (11)

Terpenes (25)

Amino acids (39)

Amino acids $(40,43,46,47)$, cinnamic acid (26), fatty acids $(3,28,29)$, paraffins $(3,19)$, sugars (47), tobacco extracts $(2,3,4,5)$

Amino acids (40, 41, 46, 47), cinnamic acid (26), fatty acids $(3,27,28)$, indenediene $(23)$, isoprene $(42)$, paraffins $(3,19)$, pigment (1), pyrrole (50), nicotine (54), sugars (47), sterols $(3,27)$, terpenes $(3,27)$, tobacco extracts $(2,4,5)$, triglycerides (27)

Amino acids (44)

Amino acids $(44,45,47)$, proteins (47)

Amino acids, proteins (47)

Amino acids $(40,47)$, proteins (47)

Amino acids $(40,46)$, nicotinamide (56), pyrrole (50), tobacco extracts $(4,5)$

Amino acids $(40,43,46)$

Amino acids $(41,46,47)$, nicotine (54), proteins (47), pyrrole (50)

Amino acids/pyrrole (41)

Amino acids $(46,47)$, nicotine (54), pigment (1), proteins (47), pyrrole (50)

Nicotine (54)

Amino acids $(46,47)$, proteins (47), pyrrole (50) Nicotine (54), pyrrole (50) Amino acids (46) 
Table 5, contd.

\begin{tabular}{l|l}
\hline Smoke constituent(s) & Leaf precursor(s) (Ref). \\
\hline
\end{tabular}

\section{G. Phenols}

$\begin{array}{ll}\begin{array}{l}\text { Catechol } \\ \text { o-Cresol }\end{array} & \begin{array}{l}\text { Caffeic acid (31) } \\ \text { Malic acid, lactic-acid } \\ \text { salt (30) }\end{array} \\ \text { Phenols (general) } & \begin{array}{l}\text { Amino acids (47), lignin (6), } \\ \text { malic and lactic acids (30), } \\ \text { pigment (1), polysaccharides } \\ (6), \text { proteins }(47), \\ \text { tobacco extracts }(4,5)\end{array} \\ & \begin{array}{l}\text { Malic acid, lactic-acid salt (30) } \\ \text { 2,4-xylenol }\end{array} \\ 3,5-x y l e n o l & \text { Sodium acetate (28) }\end{array}$

H. Miscellaneous O-containing compounds

$\begin{array}{ll}\text { Furans } & \text { Sugars }(58,60,61) \\ \text { Lactones } & \text { Sucrose }(58) \\ \text { Methanol } & \text { Pectin }(63) \\ \text { Methyl formate } & \text { Pectin (63) }\end{array}$

\section{Gases}

Carbon dioxide

Carbon disulfide

Carbon monoxide

Hydrogen

single leaf precursor may be subjected to a wide range of thermal conditions, and, depending on thermal stability, gives rise to a number of different smoke constituents under varying conditions. Returning to Figure 1 , the $\mathrm{C}_{32}$ paraffin, dotriacontane, was seen to produce a variety of dissimilar thermolysis products as a function of increasing temperature. Similarly, thermal degradation of the monosaccharide, glucose, under relatively mild conditions $\left(175^{\circ}-275^{\circ} \mathrm{C}\right.$, vacuo) resulted in products such as furfural, through reaction pathways easily visualized. The same sugar, subjected to a more drastic temperature ( $840^{\circ} \mathrm{C}$, nitrogen), however, is able to pyrosynthesize a highly condensed ring system, $\mathrm{BaP}$, presumably through free-radical reactions of some complexity. The extent to which a specific leaf constituent is subjected to the more drastic temperatures, occurring in the burn- ing cone, would appear to be partly a function of boiling point. For example, such compounds as dotriacontane, menthol, and nicotine may, to a considerable extent, volatilize in the path of the advancing burning zone. Experiments utilizing ${ }^{14} \mathrm{C}$-dotriacontane and ${ }^{14} \mathrm{C}$-menthol, incorporated into cigarettes, provided strong evidence that these distilled into the smoke stream essentially unchanged. However, the isolation and identification in tobacco-smoke condensates of many compounds such as $\mathrm{BaP}$ and dibenzacridines, the presence of which in smoke is best explained by high-temperature pyrosynthesis, indicate that a significant percentage of leaf components are subjected to the maximum temperature of the burning cone.

Pyrolysis experiments have indicated the specific temerature ranges for preferential formation of various groups of smoke constituents of particular physiological or organoleptic interest. For example, it is known that the more highly condensed aromatics are formed in highest yields, from many leaf constituents, at temeratures approaching the maximum in the burning cone. Data indicate that the volatile smoke phenols are most readily formed within the $500-700^{\circ} \mathrm{C}$ range and $1-$ alkenes in the $375-650^{\circ} \mathrm{C}$ range. A number of investigators have attempted to alter smoke composition by means of various additives which affect the burning properties of the tobacco. In cases where additives increased high-temperature thermolysis, increases in $\mathrm{BaP}$, phenol, and TPM were noted. Conversely, these smoke components were reduced by additives which promoted low-temperature degradations. Another approach toward suppressing undesirable smoke constituents involves introduction of additives which thermally decompose to form "scavenger" radicals. These radicals intervene in the normal pathway of free-radical reactions in the smoking process and, thus, inhibit the formation of $\mathrm{PAH}$. Addition of nitrate salts has fully to reduction of PAH in smoke, although, as one study suggested, several undesirable gas-phase constituents may be increased significantly.

Table 5 presents a general survey of the pyrolytic studies covered in this review and attempts, thereby, to correlate a number of compounds reportedly present in tobacco smoke with specific constituents in the cured tobacco leaf. Each class of smoke constituents will be briefly discussed, noting any particular patterns made evident in the studies cited.

Recent studies on the source of tobacco smoke acids have involved pyrolyses of acid esters, triglycerides, and acid salts, from which thermal release of free acids into the smokestream is not difficult to visualize. The presence of free acids in cigarette smoke is believed to play a significant role in overall smoke flavor and aroma (75), and their origins in leaf, therefore, are of considerable interest. Volatile acids present in tobacco leaf might be expected to occur as esters or bound to other leaf constituents as complexes or salts until released into the smoke by thermal processes.

Carbonyl compounds in smoke may arise largely from sugars, including both mono- and polysaccharides, the 
thermal degradation of which to furfurals is well-known and, in addition, from esters, triglycerides, and free acids, including amino acids. Since cured tobacco leaf contains up to $65 \%$ carbohydrate material, sugars would be expected to be major precursors of aldehydes and ketones in tobacco smoke. It is interesting to note that free or bound acids initially may give rise to ketones, which, through aldol condensations, are intermediates to a variety of cyclic and eventually aromatic compounds.

Both alkanes and 1-alkenes were shown to arise from thermolysis of the paraffins (including $C_{5}-C_{16}, C_{28}$, and $\left.\mathrm{C}_{32}\right)$ and from tobacco extracts containing paraffinic substances. It has been demonstrated that paraffins upon pyrolysis produce a homologous series of 1alkenes. Similarly, pyrolyses of triglycerides including tripalmitin and tristearin yield a homologous series of I-alkenes. Volatile alkanes $\left(C_{1}-C_{3}\right)$ and alkenes $\left(C_{2}-C_{4}\right)$ which appear in the gas phase of smoke have been produced in thermolysis of acetaldehyde and various amino acids. It has been suggested that smoke polyolefins arise from solanesol or squalene in leaf and it was shown that polyisoprenes, a number of which occur in tobacco leaf, yield cyclohexene on pyrolysis.

The aim of perhaps the greatest number of pyrolytic studies in tobacco research has been to determine the sources of aromatic hydrocarbons, especially $\mathrm{PAH}$, in tobacco smoke. This is due to the interest provoked by the biological activities of some of the more highly condensed ring compounds, such as BaP. The simpler monoaromatic hydrocarbons such as benzene, toluene, styrene, and mesitylene have been obtained by pyrolysis of such diverse compounds as dotriacontane and sodium acetate, generally beginning at temperatures substantially below those required to produce PAH. As the number of references in Table 5 implies, virtually any type of organic material subjected to temperatures of $700^{\circ} \mathrm{C}$ or higher has the potential for pyrolytic production of PAH. The minimal requirements for formation of $\mathrm{C}_{2}$ or $\mathrm{C}_{4}$ radicals, with subsequent recombinations, cyclizations, dimerizations and/or dehydrogenations, renders any carbonaceous material a candidate for PAH precursor. The ubiquitous presence of PAH in pyrolysates attained at higher temperatures makes a qualitative discussion of PAH precursors in tobacco leaf of less interest than quantitative comparisons of the efficacy of various leaf constituents to pyrosynthesize PAH. Those components of leaf extractable by non-polar solvents, for example paraffins, produce extremely high pyrolytic yields of $\mathrm{BaP}$ when compared to carbohydrates subjected to the same pyrolytic conditions. At $860^{\circ} \mathrm{C}$ under nitrogen, dotriacontane produced 70 times as much $\mathrm{BaP}$ as glucose. These data are particularly noteworthy since increased utilization of reconstituted tobacco sheet (containing stems and midribs) in cigarettes tends to raise the percentage of carbohydrates in such products.

The presence of nitrogeneous components in smoke is, naturally, a function of the nitrogen content and, in particular, the alkaloid content of leaf. The ability of nicotine to yield as series of pyridine bases on pyrolysis has long been noted. Recent studies have added pyrrole, indole, and skatole to smoke components, possibly deriving from nicotine. Extensive studies have been performed on the pyrolyses of amino acids ( $x 6$ amino acids cited in this review). Among the smoke constituents attributable to amino acids are alkyl pyrazines, amines, aniline, N-containing aromatics, indole, quinolines, toluidines, and hydrogen cyanide. Since the source of the latter compound in smoke is of particular interest, the role of amino acids in the pyrolytic production of HCN needs further investigation. Pyrolytic studies on proteinaceous materials of leaf are, at the present time, incomplete, presumably owing to difficulties of isolation and purification of protein in cured tobacco leaf. The reported presence in cigarette smoke of such $\mathrm{N}$-containing compounds as $\mathrm{N}$-nitrosamines, naphthylamines, and dibenzacridines suggests that a more extensive survey of the pyrolytic properties of the nitrogenous materials in leaf would be of value.

The volatile phenols are seen to arise from such polyphenolic leaf components as lignin and the brown pigments, and in addition, from carbohydrates, acids, amino acids, and proteins. The leaf polyphenols yield substantially greater amounts of phenols, on a per gram basis, than carbohydrates, but the latter are equally important, due to their abundance. o-Cresol and xylenols have been shown to arise from tobacco-leaf acids or acid salts. Further evidence was obtained for caffeic acid as an important precursor of catechol in smoke.

Some oxygenated components of tobacco smoke including furans, lactones, methanol, and methyl formate have been shown to arise from sugars and pectins. Furans have long been reported as thermal degradation products of sugars.

Comparatively few reports have been concerned with generation of gas-phase constituents of smoke; several of these have already been discussed under alkanes and alkenes, carbonyls, and nitrogen-containing compounds. One report (11) suggested cellulose, pigment, and water-soluble acids of leaf as principal sources of $\mathrm{CO}_{2}$ and $\mathrm{CO}$ in smoke. Pyrolysis of sulfur-containing amino acids has produced $\mathrm{CS}_{8}$ and $C O S$, both of which have been reported in cigarette smoke. The presence of other sulfur-containing gases in smoke, including dimethyl sulfide, hydrogen sulfide and methanethiol, has not been reported in these pyrolysates.

In summary, we have reviewed recent studies on pyrogenesis of tobacco smoke constituents; we have included, where appropriate, representative studies on pyrolyses of compounds reportedly present in tobacco leaf: Various experimental conditions such as temperature, gaseous environment, and thermal stability of precursor were considered in light of current understanding of the smoking process. Attempts to alter the chemical constituents of smoke by use of additives have been discussed. Finally, we have correlated various smoke constituents with pyrolyses of leaf constituents in further hopes of better understanding the complex process that produce tobacco smoke. 
Recent studies on the pyrogenesis of tobacco smoke constituents have been reviewed. Where appropriate, representative studies on pyrolyses of compounds reportedly present in tobacco leaf have been included. Various experimental conditions such as temperature, gaseous environment, and thermal stability of precursor were considered in light of current understanding of the smoking process. Attempts to alter the chemical constituents of smoke by use of additives have been discussed. Finally, various smoke constituents have been correlated with pyrolyses of leaf constituents in further hopes of better understanding the complex processes that produce tobacco smoke.

\section{ZUSAMMENFASSUNG}

Die Arbeit gibt einen Uberblick ïber neuere Veröffentlidhungen zum Thema der Pyrogenese von Inhaltsstoffen des Tabakrauches. Wo es zwedkmäßig erschienen ist, werden auch repräsentative Arbeiten über die Pyrolyse von Verbindungen, die bekanntermaßen im Blattabak vorkommen, berücksichtigt. Experimentelle Bedingungen wie Temperatur, Gasraum und thermische Stabilität von Vorstufen werden entsprechend den gegenwärtigen Kenntnissen über den Verrauchungsproze $B$ berücksichtigt. Versuche einer Veränderung der demischen Komponenten des Rauches durch Zusätze werden diskutiert. SchlieBlich werden zum besseren Verständnis der komplexen Vorgänge der Rauchbildung verschiedene Rauchinhaltsstoffe und die Pyrolyse von Blattbestandteilen korreliert.

\section{RESUME}

On a passé en revue les études récentes sur la pyrogénèse des constituants de la fumée de tabac. Certaines études sur la pyrolyse de composés présents dans la feuille de tabac ont été incluses. Différentes conditions expérimentales telles que la température, Y'environnement gazeux et la stabilité thermique de précurseurs ont été envisagées sous l'angle de la connaissance actuelle du processus de fumage. On a discuté l'usage de certains additifs destinés à modifier les constituants dhimiques de la fumée. Enfin, on a établi une corrélation entre différents constituants de la fumée d'une part, et la pyrolyse de constituants de la feuille d'autre part, dans l'espoir de mieux comprendre les processus complexes produisant la fumée de cigarette.

\section{REFERENCES}

1. Stedman, R. L.: Chem. Revs. 68 (1968) 153.

2. Schlotzhauer, W. S., and I. Schmeltz: Beitr. Tabakforsch. 4 (1968) 176.

3. Schlotzhauer, W. S., and I. Schmeltz: Beitr. Tabakforsch. 5 (1969) 5 .
4. Schlotzhauer, W. S., E. B. Higman, and I. Schmeltz: in "The chemistry of tobacco and tobacco smoke", Plenum Publishing Corp., Schmeltz, I., ed., New York, 1972.

5. Sohlotzhauer, W. S., O. T. Chortyk, H. Higman, and I. Schmeltz: Tob. Sci. 13 (1967) 153.

6. Schlotzhauer, W. S., I. Schmeltz, and L. C. Hickey: Tob. Sci. 11 (1967) $3 x$.

7. Sugawara, S., W. Kobashi, and H. Sakurai: Nippon Senbai Kosha Chuo Kenkyusho Kenkyo Hokan 112 (1970) 143 .

8. Maramatsu, M., Y. Obi, Y. Shimada, and H. Sakurai: Nippon Senbai Kosha Chuo Kenkyusho Kenkyo Hokan 112 (1970) 99.

9. Sugawara, S., U. Kobashi, and H. Sakurai: Tob. Sci. 16 (1972) 95.

10. Schlotzhauer, W. S., D. G. Bailey, A. I. Schepartz, and I. Schmeltz: Tob. Sci. 15 (1971) 97.

11. Pisklov, W. P., and I. G. Mochnachev: Ber. Inst. Tabakforsch. Dresden 18 (1971) 66.

12. Burton, H. R., and D. Burdick: Tob. Sci. 11 (1967) 180.

13. Burton, H. R., J. F. Benner, and D. Burdidk: Tob. Sci. 13 (1969) 134.

14. Burdick, D., J. F. Benner, and H. R. Burton: Tob. Sci. 13 (1969) 138.

15. Benner, J. F., H. R. Burton, and D. Burdick: Beitr. Tabakforsch. 5 (1969) 74 .

16. Rathkamp, G., and D. Hoffmann: Beitr. Tabakforsch. 5 (1970) 302.

17. Hoffmann, D., and E. L. Wynder: Natl. Cancer Inst. Monograph 286 (1968) 151.

18. Terrell, J. H., and I. Schmeltz: Science 160 (1968) 1456.

19. Schlotzhauer, W. S., I. Schmeltz, and S. F. Osman: Chem. Ind., London, 1970, 1377.

2o. Henderson, W., G. Englington, R. Simmonds, and J. E. Lovelock: Nature 219 (1968) 1012.

21. Brown, R. A.: Anal. Chethis 43 (197x) 900.

22. Jenkins, R. S., R. H. Newman, R. D. Carpenter, and T. S. Osdene: Beitr. Tabakforsh. 5 (1970) 295.

23. Hoffmann, D., and G. Rathkamp: Anal. Chem. 44 (1972) 899.

24. Galin-Vacherot, M.: Eur. Polym. J. 7 (1971) 1455.

25. Dare, D. L., I. D. Entwistle, and R. A. W. Johnstone: J. Chem. Soc. C. 8 (1968) 977.

26. Jones, T. C., and I. Schmeltz: J. Org. Chem. 34 (1969) 645 .

27. Halaby, G. A., and I. S. Fagerson: Third International Congress of Food Science and Technology, Washington, D. C. (1970).

28. Schmeltz, I., and W. S. Schlotzhauer: J. Chem. Soc. D. 12 (1969) 681.

29. Rudenko, A. P., and I. Y. Konsinska: J. Org. Chem. USSR 5 (1969) 680.

3o. Geisinger, K. R., T. C. Jones, and I. Schmeltz: Tob. Sci. 14 (1970) 89.

$3 x$. Jones, T. C., and I. Schmeltz: Chem. Ind., London, 43 (1968) 1480.

32. Zane, A., and S. H. Wender: Tob. Sci. 7 (1963) 21. 
33. Patterson, J. M., C. Y. Shiue, and W. T. Smith, Jr.: Submitted to J. Org. Chem.

34. Miyagawa, M.: Yukagaku 18 (1969) 854.

35. Higman, E. B., I. Sdhmeltz, H. C. Higman, and O. T. Chortyk: Submitted to J. Agr. Food Chem.

36. Kitamura, K.: Bull. Chem. Soc. Japan 44 (1971) 1606.

37. Liu, M. T. H., and K. J. Laidler: Can. J. Chem. ${ }^{6} 6$ (1968) 479.

38. Come, G. M., M. Dzierzynski, R. Martin, and M. Niclaus: Rev. Inst. Fr. Petrole Ann. Combust. Liquides 23 (1968) 1365.

39. Kirret, O., E. Kullik, and M. Luus: Eesti NSV Tead. Akad. Toim. Keem., Geol. 18 (1969) 307.

40. Patterson, J. M., M. L. Baedecker, R. Musick, and W. T. Smith, Jr.: Tob. Sci. 13 (1969) 26.

4x. Patterson, J. M., W. Chen, and W. T. Smith, Jr.: Tob. Sci. 15 (1971) 98.

42. Oro, J., J. Han, and A. Zlatkis: Anal. Chem. 39 (1967) 27.

43. Patterson, J. M., N. F. Haidar, E. P. Papadopoulos, and W. T. Smith, Jr.: Submitted to J. Org. Chem.

44. Kato, S., T. Kurata, R. Ishitsuka, and M. Fujimaki: Agr. Biol. Chem. 34 (1970) 1826.

45. Fujimaki, M., S. Kato, and T. Kurata: Agr. Biol. Chem. 33 (1969) 1144 .

46. Smith, W. T., Jr., C. Y. Shiue, and J. M. Patterson: 24th Tobacco Chemists' Research Conference, Montreal, Canada, 1970 .

47. Higman, E. B., I. Schmeltz, and W. S. Schlotzhauer: J. Agr. Food Chem. 18 (1970) 636.

48. Chortyk, O. T.: in "The chemistry of tobacco and tobacco smoke", Plenum Publishing Corp., I. Schmeltz, ed., New York, 1972.

49. Schmeltz, I., W. S. Schlotzhauer, and E. B. Higman: Beitr. Tabakforsch. 6 (1972) $\times 34$.

50. Patterson, J. M., A. Tsamasfyros, and W. T. Smith, Jr.: J. Heterocyclic Chem. 5 (1968) 727.

5x. Hurd, C. D., A. R. Macon, J. I. Simon, and R. V. Levetan: J.A.C.S. 84 (1962) 4509.

52. Woodward, C. F., A. Eisner, and P. G. Haines: J.A.C.S. 66 (1944) 911.

53. Jarboe, C. H., and C. J. Rosene: J. Chem. Soc. 1961, 2455.

54. Kaburake, Y., S. Sugawara, U. Kobashi, and T. Doihara: Nippon Nogei Kagaku Kaishi 44 (1970) 224.
55. Van Duuren, D. L., J. A. Bilbao, and C. A. Joseph: J. National Cancer Institute 25 (1960) 53.

56. Bruzel, A. R., and I. Schmeltz: Tob. Sci. 15 (1971) 51.

57. Fagerson, I. S.: J. Agr. Food Chem. 17 (1969) 747.

58. Johnson, R. R., E. D. Alford, and G. W. Kinzer: J. Agr. Food Chem. 17 (1969) 22.

59. Houminer, Y., and S. Patai: Isr. J. Chem. 7 (1969) 513.

6o. Gager, F. R., Jr., J. W. Nedlodk, and W. J. Martin: Carbohyd. Res. 17 (1971) 327.

61. Gager, F. L., Jr., J. W. Nedlock, and W. J. Martin: Carbohyd. Res. 17 (197x) 335.

62. Benner, J. F., H. R. Burton, and D. Burdick: Beitr. Tabakforsch. 5 (1969) 134 .

63. Zamorani, A., G. Roda, and G. Lanzarini: Ind. Agr. 9 (1971) 35.

64. Burdick, D., and H. R. Burton: Tob. Sci. 13 (1969) 16.

65. Schmeltz, I., and W. S. Schlotzhauer: Nature 219 (1968) 370.

66. Jenkins, R. W., R. H. Newman, and M. K. Chavis: Beitr. Tabakforsch. 5 (1970) 299.

67. Chopra, N. M., J. J. Domanski, and N. B. Osborne: Beitr. Tabakforsch. 5 (1970) 167.

68. Chopra, N. M., and N. B. Osborne: Anal. Chem. 43 (1971) 849.

69. Chopra, N. M., and L. R. Sherman: Anal. Chem. 44 (1972) 1036.

7o. Patterson, J. M., C. H. Issidorides, V. C. Groutas, and W. T. Smith, Jr.: Chem. Ind., London, 1972, 337.

71. Patterson, J. M.: Personal communication.

72. Newsome, J. R., and C. H. Keith: Tob. Sci. 9 (1965) 65.

73. Pyriki, C., and R. Muller: Ber. Inst. Tabakforsch. Dresden 6 (1959) 231.

74. Touey, G. P., and R. C. Mumpower: Tob. Sci. I (1957) 33.

75. Stedman, R. L., D. Burdick, W. J. Chamberlain, and I. Schmeltz: Tob. Sci. 7 (1963) 166.

The authors' address:

US Dept. of Agriculture, Agricultural Research Service, Richard B. Russell Agricultural Research Center, P.O, Box 5677, Athens, Georgia, 30604, USA.

\section{Erratum}

Page 166, left column:

In the $1^{\text {st }}$ and $3 r d$ line the correct measuring unit should read " $\mu$ g per $g$ ", and not "mg per g". 